\title{
PERANAN ALAT BANTU PENGIRIMAN ARSIP AEROCOM PNEUMATIC TUBE SYSTEM PADA PEMERIKSAAN VERTEBRAE CERVICAL DENGAN KASUS TRAUMA
}

\author{
Ryzki Mega Mentari ${ }^{1}$ Nanang Sulaksono ${ }^{2)}$ \\ ${ }^{1}$ Rumah Sakit Melinda 2 Bandung \\ 2Poltekkes Kemenkes Semarang
}

Email :mentariryzkimega@gmail.com

\begin{abstract}
Background :The cervical vertebrae consist of seven vertebral bones separated by intervertebral discs and connected by complex ligamentous tissue. Examination of cervical vertebrae includes Axial, Lateral, RPO and LPO AP projections. Axial AP projections are carried out with $15-20^{\circ}$ cephalad angles. At PKU Muhammadiyah Hospital Gamping vertebrae radiographic examination cervical AP projection was done without cornering this case there was a difference with the theory so the author wanted to know more about the examination procedure.

Methods :This type of research is qualitative research with a case study approach. This research was conducted at the Radiology Installation of PKU MuhammadiyahGamping Hospital and was carried out in March - May 2018. This research was carried out by observation, documentation, radiogarfer interviews and radiology doctors. Results :The results of the study found that cervical vertebrae radiographic examination procedures in trauma cases used two projections, namely AP and Lateral projections. On vertebrae examination cervical projection of AP is done without cornering. The reason for not being cornered is because the radiograph has revealed the corpus, intervertebral disc, spinousprocesus. Cervical vertebrae examination with trauma cases requires further action. In the Radiology Installation PKU Muhammadiyah Hospital, Gamping, was assisted by the delivery of aerocom pneumatic tube system files, in its role this tool was very helpful if the sending doctor wanted to immediately find out the radiographic results of the patient with the trauma case.
\end{abstract}

Key Word :trauma, vertebrae cervical, radiografi

\section{Pendahuluan}

Vertebrae cervical manusia pada dasarnya terdiri dari tujuh tulang vertebrae yang terbentang dari occipital cranium sampai thoracal. Vertebrae cervical mempunyai fungsi yang sangat penting yaitu tempat lewatnya saraf dari otak yang terhubung keseluruh tubuh (Sloane, 2004).

Vertebrae cervical dapat mengalami berbagai kelainan, baik karena trauma ataupun karena penyebab patologis lain. Beberapa kelainan yang terjadi pada kolumna vertebrae yaitu berupa fracture, metastases, scoliosis, spondylosis, kyphosis, dan spondylolisthesis (Frank, 2012).Trauma dapat di definisikankejadiansecaratiba-tiba, takterduga, kuat atau kejadian karena kekerasan peristiwa (Frank, 2012).

Pengiriman arsip yang mudah dan cepat sangat di perlukan terutama untuk pasien dengan diagnose trauma cervical di Instalasi Gawat Darurat. Pasien Instalasi Gawat Darurat membutuhkan pertolongan yang cepat jika terdapat diagnose seperti trauma dan fraktur yang memerlukan pemeriksaan ke radiologi, kemudian untuk mempercepat pengiriman kedokter pengirim dapat menggunakan bantuan alat Aerocom Pneumatic Tube System, sehingga mempercepat untuk melanjutkan tindakan yang akan di lakukan untuk keselamatan pasien (Sugiarto danWahyono, 2009).

Menurut Merril's (2016) pada pemeriksaan vertebrae cervical meliputi proyeksi AP Axial, Lateral, RPO dan LPO.Padaproyeksi AP Axial di lakukan dengan penyudutan $15-20^{\circ}$ cephalad, bertujuan agar tidak terjadi superposisi pada mandibular dan pertengahan dari vertebrae cervical.

Instalasi Radiologi RS PKU Muhammadiyah Gamping melakukan pemeriksaan vertebrae cervical dengan proyeksi AP dan Lateral.Namun pada proyeksi AP tidak di lakukan penyudutan. Hal ini tidak sesuai dengan teori yang ada.

Di Instalasi Radiologi RS PKU Muhammadiyah Gamping menyediakan alat bantu pengiriman arsip Aerocom Pneumatic Tube System. Dalam melakukan pengiriman 
hasil bacaan dari ruang radiologi keInstalasi Gawat Darurat (IGD) dan sehingga tidak perlumenunggu hasil foto hingga jadi jika hasil foto sudah bagus pasien bias kembali ke Instalasi Gawat Darurat (IGD).

\section{Metode}

Metode penelitian yang digunakan adalah kualitatif dengan pendekatan studi kasus yang dilaksanakan pada bulan Maret hingga Mei 2018 di Instalasi Radiologi RS PKU Muhammadiyah Gamping.Metode pengumpulan data yang digunakan yaitu observasi, wawancara, dan studi dokumen kemudian di analis amelalui beberapa tahapan antara lain :tahapan pengumpulan data, tahapan reduksi data, tahapan penyajian data, tahapan pembahasan dan kesimpulan.

\section{Hasil d Pembahasan}

1. Prosedur Pemeriksaan Vertebrae Cervical Pada Kasus Trauma Di Instalasi Radiologi RS PKU Muhammadiyah Gamping

Persiapan alat dan bahan alat yang di gunakan antara lain pesawat sinar-x siappakai, kaset ukuran $24 \times 30 \mathrm{~cm}$, computed tomography, printer, aerocom pneumatic tube system.

Persiapan pasien pada pemeriksaan vertebrae cervical tidak memerlukan persiapan khusus, hanya melepas barangbarang yang terbuat dari logam yang dapat menyebabkan artefak.

Teknik pemeriksaan radiografi cervical dengan kasus trauma di Instalasi Radiologi RS PKU Muhammadiyah Gamping menggunakan dua proyeksi yaitu AP dan Lateral.

a. Fotoproyeksi AP

1) Posisipasien : Supine di atas brancard

2) Posisi objek : Pasien di atur menghadap ke tabung sinar- $X$, hal ini di lakukankarenapasienmengalami trauma dan tidak kooperatif. Kedua lengan berada di samping tubuh. MCP leher di atur pada pertengahan kaset

3) Central ray : Vertikal tegak lurus

4) Central point : Cervical ke IV

5) FFD $: 100 \mathrm{~cm}$

6) Kaset :24x30 cm

7) Faktoreksposi : $55 \mathrm{kVp}, 5 \mathrm{mAs}$

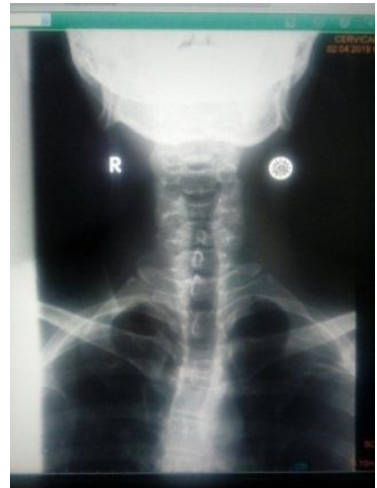

Gambar 1 Hasil radiograf proyeksi AP

b. Proyeksi Lateral

1) Posisi pasien : Supine di atas brancard

2) Posisi obyek :Pasien di atur mengahadap ketabung sinar- $\mathrm{X}$, hal ini di lakukan karena pasien mengalami trauma dan tidak kooperatif. Kedua lengan berada di samping tubuh. MCP leher di atur pada pertengahan kaset

3) Central ray : Horizontal tegak lurus

4) Central point : Cervical ke IV

5) FFD : $100 \mathrm{~cm}$

6) Kaset : $24 \times 30 \mathrm{~cm}$

7) Faktoreksposi : $55 \mathrm{kV}, 5 \mathrm{mAs}$

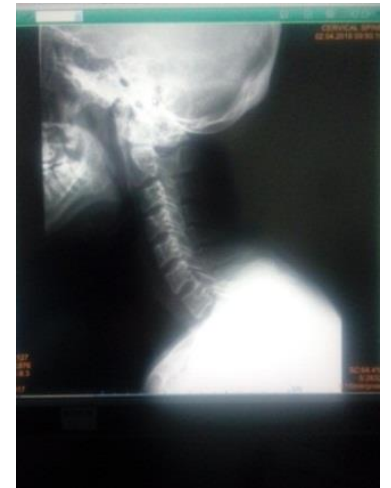

Gambar 2 Hasilradiografproyeksi lateral

Alasan mengapa pemeriksan radiografi vertebrae cervical dengan proyeksi AP di lakukan tanpa penyudutan pada kasus trauma.Pemeriksaan pasien vertebrae cervical pada kasus trauma di Instalasi Radiologi RS PKU Muhammadiyah Gamping menggunakan proyeksi AP (tanpa penyudutan) dan Lateral ini karena dalam pemeriksaan cervical tanpa penyudutan sudah menampakkan hasil yang sudah bagus. 
Bagaimana peranan aerocom pneumatic tube system sebagai alat bantu pengiriman arsip pada pemeriksaan cervical dengan kasus trauma di Instalasi Radiologi RS PKU Muhammadiyah Gamping. Beberapa peranan aerocom pneumatic tube system di Instalasi Radiologi RS PKU Muhammadiyah Gamping ini yaitu pengiriman lebih cepat dan waktu lebih efektif.

System pengoperasian dari aerocom pneumatic tube system sebagai alat bantu pengiriman arsip pada pemeriksaan vertebrae cervical dengan kasus trauma di Instalasi Radiologi RS PKU Muhammadiyah Gamping yaitu, ambil tube sesuai kebutuhan, setelah itu masukan berkasnya yang akan di kirim kemudian posisikan tubenya pada pipa, kemudian pilih kode sesuai dengan tujuan ruang yang akan di kirim berkas tersebut.

Berdasarkan observasi dan wawancara mendalam dengan radiografer, dokter radiologi mengenai pemeriksaan cervical dengan kasus trauma di Instalasi Radiologi RS PKU Muhammadiyah Gamping, maka peneliti akan membahas tentang :

Teknik pemeriksaan radiografi vertebrae cervical dengan kasus trauma di Instalasi Radiologi RS PKU Muhammadiyah Gamping.

Persiapan alat dan bahan pada pemeriksaan vertebrae cervical menurut Bontrager (2014), pasien dengan indikasi trauma di lakukan dengan persiapan alat dan bahan yang di gunakan sebagai berikut :pesawat sinar-X, marker, kaset, dan film ukuran 24x30 cm, marker. Persiapan alat dan bahan yang di gunakan untuk pemeriksaan cervical di Instalasi Radiologi RS PKU Muhammadiyah Gamping ini meliputi : pesawat sinar-X siap pakai, Imaging Plate, ukuran 24x30 cm, marker yang berikan pada proses editing, Computed Raiography (CR), printer, pengganjal.

Persiapan pasien pada pemeriksaan vertebrae cervical pada kasus trauma di RS PKU Muhammadiyah Gampng tidak ada persiapan khusus hanya saja pasien harus melepas benda-benda logam yang dapat menimbulkan artefak. Hal ini sesuai dengan Bontrager (2014) yang menyatakan bahwa tidak ada persiapan khusus untuk pasien, hanya saja melepaskan benda-benda logam yang dapat mengganggu hasil gambaran radiograf. Namun petugas harus memberikan penjelasan hal apa saja yang harus di lakukan saat melakukan pemeeriksaan.

Teknik pemeriksaan radiografi menurut Merril's (2016) pada pemeriksaan vertebrae cervical meliputi proyeksi AP Axial, Lateral, RPO dan LPO. Pada proyeksi AP Axial di lakukan dengan penyudutan $15-20^{\circ}$ cephalad yang bertujuan agar tidak terjadi super posisi pada mandibular dan pertengahan dari vertebrae cervical.Instalasi Radiologi RS PKU Muhammadiyah Gamping melakukan pemeriksaan vertebrae cervical dengan proyeksi AP dan Lateral. Namun pada proyeksi AP tidak di lakukan penyudutan.

Alasannya mengapa pada pemeriksaan vertebrae cervical di Instalasi Radiologi RS PKU Muhammadiyah Gamping hanya menggunakan 2 proyeksi saja yaitu AP, Lateral dan proyeksi AP tidak di lakukan penyudutan karena di Instalasi Radiologi RS PKU Muhammadiyah Gamping melakukan semua pemeriksaan termasuk pemeriksaan cervical sesuai SOP rumah sakit tersebut dan dalam hal ini dokter juga sudah merasa cukup pada saat melakukan expertise dengan 2 proyeksi saja yaitu proyeksi AP dan proyeksi Lateral.

Bagaimana peranan aerocom pneumatic tube system sebagai alat bantu pengiriman arsip pada pemeriksaan cervical dengan kasus trauma di Instalasi Radiologi RS PKU Muhammadiyah Gamping Beberapa peranan aerocom pneumatic tube system di Instalasi Radiologi RS PKU Muhammadiyah Gamping ini yaitu pengiriman lebih cepat dan waktu lebih efektif. Beberapa hal di atas di butuhkan untuk pasien salah satunya adalah pasien pada pemeriksaan radiografi vertebrae cervical dengan kasus trauma agar pasien lebih cepat mendapatkan penanganan atau tindakan yang lebih lanjut.

System pengoperasian dari aerocom pneumatic tube system sebagai alat bantu pengiriman arsip pada pemeriksaan vertebrae cervical dengan kasus trauma di Instalasi Radiologi RS PKU Muhammadiyah Gamping yaitu, ambil tube sesuai kebutuhan, setelah itu masukan berkasnya yang akan di kirim kemudian posisi katubenya pada pipa, kemudian pilih kode sesuai dengan tujuan ruang yang akan di kirim berkas tersebut.

\section{Simpulan}

1. Teknik pemeriksaan vertebrae cervical pada kasus trauma di Instalasi Radiologi RS PKU Muhammadiyah Gamping di lakukan 
dengan menggunakan proyeksi AP dan Lateral.

2. Pemeriksaan radiografi vertebrae cervical pada proyeksi AP yang di lakukan tanpa penyudutan yaitu Karena dalam pemeriksaan cervical tanpa penyudutan sudah memberikan informasi yang cukup. Tidak di sudutkan hasilnya kurang lebih sama di bandingkan dengan yang di sudutkan dan saat dokter radiologi melakukan expertise juga tidak ada complain. Dalam proyeksi AP yang di lakukan tanpa penyudutan ini dapat memperlihatkan pada procesusspinosus, corpus dan diskus intervertebralis tetapi pada bagian posterior cervical tidak bias terlihat terlebih lagi untuk kasus trauma, sehingga untuk kasus trauma dokter radiologi lebih melihat pada proyeksi Lateral.

3. Aerocom Pneumatic Tube System di Instalasi Radiologi RS PKU Muhammadiyah Gamping memiliki peranan penting salah satunya pada pemeriksaan radiografi vertebrae cervical dengan kasus trauma, dengan menggunakan alat bantu pengiriman arsip aerocom pneumatic tube sytem dapat segera mendapat informasi diagnostik yang lebih cepat dan tidak perlu menunggu di Radiologi, sehingga pasien dapat segera mendapatkan penanganan atau tindakan yang lebih lanjut.

\section{Daftar Pustaka}

Agus Sugiarto, Teguh Wahyono. 2009.

Manajemen Kearsipan Modern

Yogyakarta Gava Media 2005.

Bruce W Long, Jeannean Hall Rollins, Barbara J Smith 2016 Merrill's Atlas of Radiographic Positions and Procedures, Thirteenth Edition, Volume One.

Frank, Eugene D. 2012. Merril's atlas of Radiographic Positioning and Radiologic Procedures, Volume One, Twelfth Edition. Mosby : St. Louis.

Sloane, Ethel. 2004 .Anatomi dan Fisiologi untuk Pemula, Jakarta EGC. 